\title{
EFFECT OF UNUSUAL WEATHER ON CEREAL CROP PRODUCTION AND HOUSEHOLD FOOD SECURITY
}

\author{
Hem R. Regmi, MSc. Statistics ${ }^{3}$
}

\begin{abstract}
For the third consecutive year, drought conditions have been severely affecting agricultural production in Nepal and in some cases turning traditionally surplus production areas into deficit ones. In addition to the heavily drought affected Mid- and Far-Western Regions, flood exacerbated by hailstones and crop diseases in various VDCs caused extensive crop loss. Drought particularly affected the traditionally food surplus areas of the Eastern Terai, particularly Siraha, Saptari and Dhanusha which reported a decline in paddy production of about 30\%. A total of 109,855 hectares of paddy land (7.09\%) remained fallow in 2006/07 as farmers were unable to plant due to drought. In addition, yields were lower by almost $6 \%$. Paddy crop production consequently declined by $12.5 \%$ compared to last year. The total food grain shortfall for the year 2006/07 has been calculated at 187,748 Mt assuming favorable weather conditions for the winter crop wheat and barley.
\end{abstract}

\section{Introduction}

During fiscal year 2005/06 food production in Nepal was adversely affected by drought with reported decreases in the average paddy and wheat production of 2.0 and $3.3 \%$ respectively. The long dry spell of the 2005/06 winter particularly affected subsistence hill and mountain farmers in the Mid- and Far-Western regions. High crop losses resulted in adoption of negative coping strategies and livelihoods of many subsistence farmers and landless populations were threatened.

Weather conditions were again unfavorable during the summer monsoon of 2006/07. For a third consecutive year, the overall rainfall during the period from June through September was below normal. Variation in spatial and temporal rainfall patterns badly affected the summer paddy crop, particularly those crops relying $100 \%$ on rainfall for irrigation. Known as the granary of Nepal, the Terai which normally produces $56 \%$ of the national grain supply was severely affected, with overall production losses over $14 \%$.

Nepal is vulnerable to several types of natural disasters such as: floods, earthquakes, drought, cold waves, landslides, hailstorms, disease epidemics, glacial lake outburst flood (GLOF), and fires. On top of that, various factors such as rapid population growth and improper land use have contributed to increased vulnerability of natural disasters and disease epidemics. Drought, floods and landslides are the most recurrent natural disasters that annually cause significant material and human losses.

\section{Rainfall situation}

The monsoon rains normally start around $10^{\text {th }}$ of June and continue up to around $23^{\text {rd }}$ of September. About $80 \%$ of the annual rainfall in the country occurs during this period. Overall rainfall compared to a normal year and that of the last two monsoons is presented in (Fig. 1). On average rainfall was about $16 \%$ below normal. Only the weather stations at Simara, Janakpur, Jumla, and Nepalgunj recorded normal monsoon precipitation (Fig. 1). However, these so called normal recorded precipitation levels can mostly be attributed to the heavy

\footnotetext{
${ }^{3}$ Senior Statistical Officer, Agribusiness, Promotion and Statistics Division, MOAC, Singh Durbar. Email: hregmi1@hotmail.com
} 
rainfall received in the last week of August and during the second and third week of September - too late to support a productive harvest.

Fig. 1 Total Monsoon Precipitation as percentage of normal

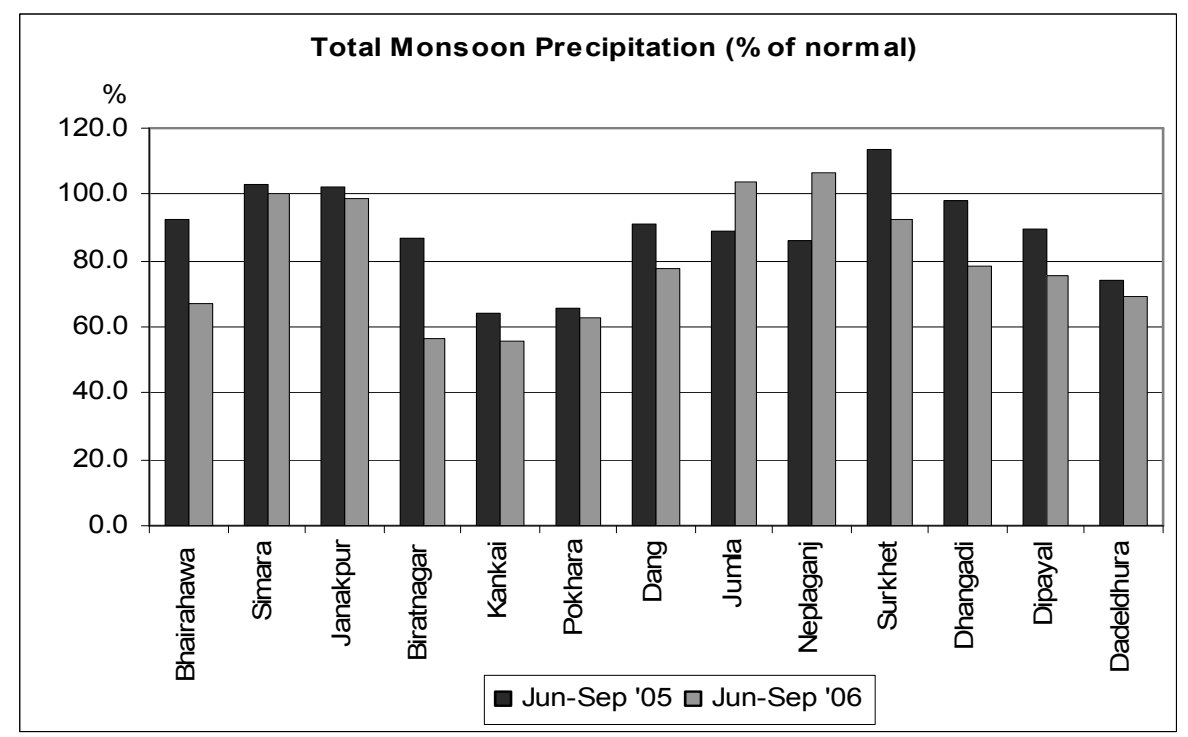

Source: Department of Hydrology and Meteorology

Besides the less than normal rainfall, the main problem was the variation in the spatial and temporal pattern of rain. Although the monsoon started earlier than normal rain intensity was weak with below normal precipitation and drought conditions in the districts of Saptari, Siraha, Dhanusa and Udayapur - resulting in a crop deficit in these traditionally crop surplus districts. During July, Eastern, Central, and Western regions received $40 \%$ less than normal precipitation. The Far- and Mid- Western regions had above normal rainfall during this period. August was a particularly dry month with the entire country facing a shortage of rain during a critical time for crop growth. Exceptions to this general pattern were pockets in the Mid- and Far-Western regions which received more than $180 \%$ of normal rainfall. In addition, heavy rainfall at the end of the month caused floods and landslides in Western, Mid-Western, and Far-Western districts of Nawalparasi, Jajarkot, Banke, Bardiya, Surkhet, Bajura, Achham, Doti, Baitadi, and Darchula resulting in significant crop damage. During the month of September, precipitation was about normal or above normal in the drought affected districts in the Eastern and Central Terai. This slightly improved the standing paddy crop condition. Unfortunately, heavy rainfall during the second and third week of September created flood and landslides in the districts of Banke, Bardiya and Achham, again resulting in crop loss.

\section{Agricultural Production}

With almost $67 \%$ of agricultural land being rain fed, the annual agricultural output is highly dependent on weather conditions. The Department of Hydrology and Meteorology pronounced last winter (November 2005-February 2006) as the driest since the 1960s. The winter rainfall was less than $30 \%$ of normal with some areas receiving no precipitation. Consequently, the winter wheat production declined by 3.35\% compared to 2004/05. Similarly, last year's (2005) erratic monsoon rains caused a decline of $2 \%$ in the national paddy production. This monsoon 
(2006) produced a comparable situation with consequent implications for the summer crop yield for the third consecutive year.

Fig. 2 Cereal Food Production in Nepal during 1994/95-2005/06

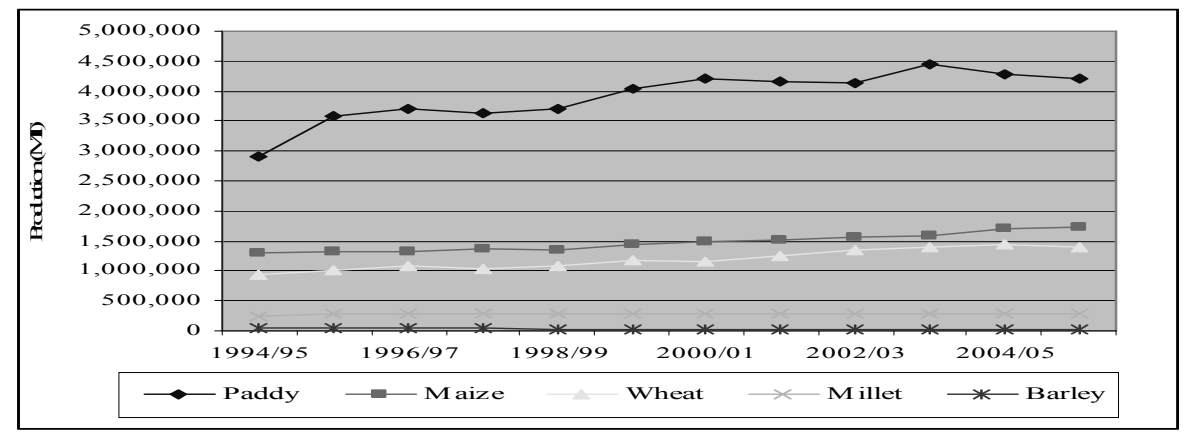

Source: Statistical Information on Nepalese Agriculture (time series), MOAC 2005, Kathmandu

Fig. 2 shows the trend in cereal production since 1994/95. Since the boost in paddy production from 3.6 million Mt in 1998 to 4.0 million Mt in 1999, the average annual output has remained around 4.2 million Mt. In 2003, the paddy production peaked at 4.45 million Mt as a result of very good weather conditions. Since then there has been a decline in paddy production mainly due to ongoing drought conditions. Other cereal crops such as wheat and maize have on average maintained a slightly positive annual growth rate, while the production of millet has remained constant at an annual output of around 290,000 Mt. The annual production of barley has declined on average by $2.3 \%$ per year since 1994/95 to less then 28,000 Mt in 2005/06.

Fig. 3 Contribution to National Cereal Production (2004/05)

Fig. 3a - By Development Region

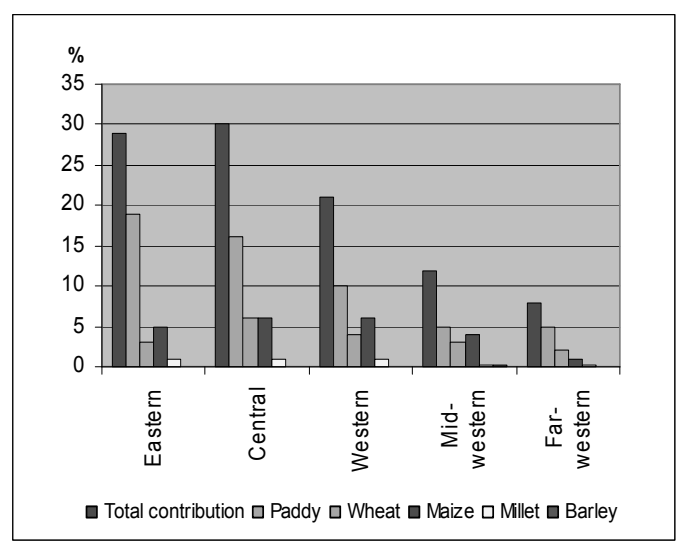

Fig. 3b - By Ecological zone

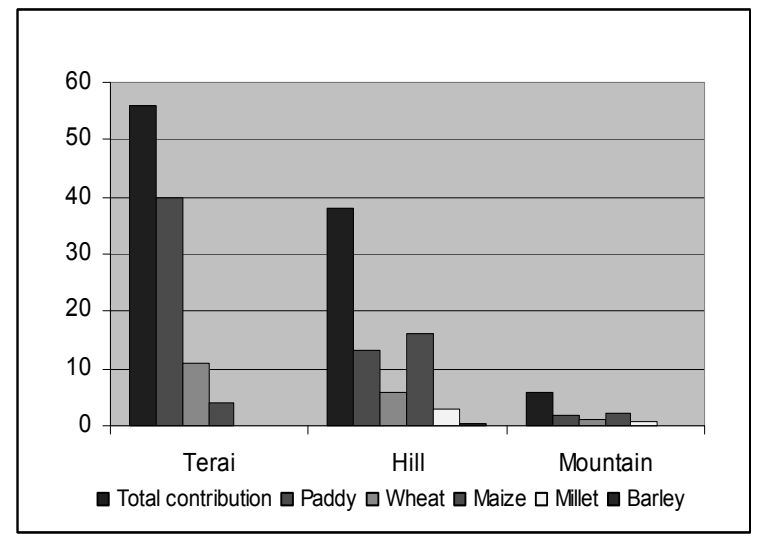

Source: Statistical Information on Nepalese Agriculture (time series), MOAC 2005, Kathmandu

The annual total crop area of Paddy, maize, and wheat account over $70 \%$ and $95 \%$ of all food grain production in Nepal. The largest share of total crop production comes from the Central Region, (nearly one-third), followed by the Eastern and Western Regions. The Terai is most important in the production of the national cereal supply, contributing about $56 \%$ yearly (Fig. $3)$. 
The prolonged drought and adverse weather conditions badly affected the summer crops in 2006/07, and in particular, the un-irrigated paddy crop in different parts of the country. Annex Table 1 shows the production estimates for the main cereal summer crops at the national level. These figures are based upon revised estimates from DADO offices from all 75 districts.

\section{Paddy production}

Overall paddy production decreased by $12.55 \%$ compared to last year. Considering the trend in annual paddy production since 1994/95, there is a gap of almost 1 million Mt or $21 \%$ compared to the forecasted trend in paddy production (Annex Graph 1) for the 2006/07 crop year. Regionally, the Eastern Development Region was hardest hid by the drought, particularly the districts of Saptari, Siraha, Dhanusa and Udayapur, where output declined between $27 \%$ and $39 \%$ compared to last year. On average yields in the Eastern Development Region were about $10 \%$ lower than last year and almost $15 \%$ of paddy land was left fallow. The Central Development region lost $9.4 \%$ in output compared to last year, mainly due to unplanted paddy land and a slight decrease in yields $(-2.2 \%)$. The Western and Mid-Western Development Regions lost $6.7 \%$ and $7.8 \%$ in output respectively mainly due to decrease in yields. Production in the Far-Western Development Region increased by $2.4 \%$ as more land was put under paddy cultivation and weather conditions improved. Paddy losses were highest in the Terai $(14.4 \%)$, mostly due to the inability of farmers to transplant paddy due to the drought, leaving about 93,628 hectares of paddy land unplanted. Yields decreased by $6.5 \%$. In the Hill and Mountain regions, paddy production declined by $6.6 \%$ and $7.7 \%$ respectively. About half of this was due to less area planted with the other half due to a decrease in crop yields.

\section{Maize Production}

At the national level, the maize harvest was not affected by the drought, and in fact increased by $4.93 \%$ compared to last year. Compared to the trend in maize production since $1994 / 95$, there is positive difference of $82,609 \mathrm{Mt}$ or $5 \%$ more then the forecasted trend (Annex Graph 2).

\section{Millet Production}

The area under millet production has increased slightly compared to last year $(1.33 \%)$. However, the national production of millet decreased by $2.1 \%$ compared to last year and compared to the trend production forecast, there's a negative gap of $8,880 \mathrm{Mt}$ or $3 \%$ (Annex Graph 3). Millet contributes only 3.7\% to the national cereal production, however it is a key crop in several Hill and Mountain districts including Mugu, Dolpa, Jumla, Baglung, Syangja, Rasuwa, Sindhupalchowk, Sindhuli, Okhaldhunga and Khotang.

\section{Prospects for winter wheat production}

Early indications suggest that the planting of wheat has been timely. Due to late rainfall in September, the soil is moist and the conditions for germination are good. Land left fallow for paddy cultivation will be used for wheat production and it is likely that the area planted with wheat and consequently production will increase significantly in the drought affected districts. In addition, the Government of Nepal has initiated subsidized seed distribution through the DADO, rehabilitation of irrigation systems and shallow tube wells in an effort to boost the winter crop production in 20 Terai and 25 hill districts as a special relief package. The above would suggest a positive scenario for national wheat production for 2006/07. Following the trend in wheat production, an output of around 1.5 million Mt is assumed (Annex Graph 4). 


\section{Food supply and demand balance}

Nepal was self-sufficient in food grain production until 1990. Thereafter, the increase in food grain production fell short of population growth, and from 1990 to 1999, national production in Nepal was unable to meet the population's need. As a result of the leap in cereal production in 1999, Nepal became once again self-sufficient in food grains. Due to drought conditions in 2005/6, production fell short by 23,168 Mt, and for this crop year (2006/07), a negative balance between 200,000 and $300,000 \mathrm{Mt}$ is expected, mainly due to the impact of drought and other natural calamities (Annex Table 3).

The food grain production and requirement balance varies across regions and ecological belts (see Annex Table 2). The Eastern region, across all ecological belts, Mountain, Hill and Terai, is a surplus area. The Terai, where about half of Nepal's population lives, is the granary of the country with an overall surplus of almost $125 \%$. The mountain belt, with $8 \%$ of the total population, is a deficit area, producing about three-fourths of its requirements, while the Hill belt, with $44 \%$ of the population, producing about $16 \%$ less than its regional requirement. Assessment of the summer crop situation has indicated that some districts which are traditionally food surplus will turn into food grain deficit areas. The expectation is that the districts Siraha and Saptari which are food surplus districts in normal years will turn into food grain deficit districts due to prolonged drought this year, despite expected increases in wheat production in the upcoming winter season.

Dang, Surkhet and Bardiya remain food grain surplus districts. Banke and Danusha have records of fluctuating production. In 2003/04 both districts (Banke and Dhanusha) were food grain surplus producing areas while in 2005/06 they recorded a negative food grain balance which is expected to further deteriorate in 2006/07.

In Udayapur, Pyuthan and Bajura the level of food grain shortage with regard to requirement has further worsened. In Doti and Achham the food grain balance situation has improved, even though it remains negative. With the winter season on its last step; it is still too early to make exact predictions about the food grain supply and requirement balance for the year 2006/07. However, assuming that the optimistic scenario for the winter wheat production will occur, the total cereal shortage is expected to be nearly about 188,000 Mt. Assuming that most of the food grain shortage will be met through increased formal and informal private imports, a certain amount of food aid imports are required to assist those who lack the ability to acquire sufficient food through the market channels.

\section{Household Food Security and Livelihoods and coping strategies}

Sufficient or insufficient food supply at the national or district level provides an indication of the overall food security situation. It does however not necessarily directly correspond to household food security. The latter is determined by a household's ability to access sufficient food. The main livelihoods in the Terai and Hill districts are crop farming and wage labor (agricultural, services or construction). In the Mountain areas subsistence farming and pottering are the main livelihood options. In some Mountain areas, gathering medicinal herbs during certain times of the year may provide an additional income source. Poor and landless people's main asset is labor. In rural Nepal, employment opportunities are however seasonal and depend on the harvesting cycle.

In many areas the recent conflict has had a major impact on people's livelihoods: restrictions in transportation meant that farmers could not sell there surplus production on the market and/or led to short term food crises in areas not accessible by roads. Development activities ceased in many parts of the country, contributing to widespread unemployment in the 
country side, and in some cases agricultural assets such as land were confiscated. The government's food safety net program through the Nepal Food Corporation was limited to the district headquarters as many of the food grain depots in remote areas were closed down, depriving the most vulnerable in remote rural areas from subsidized food grain support. In many of the affected communities, vulnerability was exacerbated by the displacement and migration of young and able men, leaving women, children and elderly behind to care for the land. With the recent ceasefire and signing of the peace treaty, it is expected that many people will return back to their home villages. This type of situation would complicate the reintegration process and will make it difficult for these people to regain sustainable livelihoods as many of the displaced people will be returning to districts already suffering from food shortages.

In case of external shocks, such as drought and unfavorable weather conditions, that may compromises a household's potential to produce sufficient food, loss of income opportunities, or high food prices in the markets, a household implements a series coping strategies for its survival. Agricultural wage labor, borrowing and seasonal out-migration to India are the most commonly adopted coping mechanisms in Nepal.

\section{Poverty and risk of food insecurity}

Despite the conflict situation, poverty decreased from $42 \%$ in $1995-96$ to $31 \%$ in $2003-04$. Key factors contributing to the decline in poverty were a substantial increase in remittances, higher agricultural wages, increased connectivity and a decline in the dependency ratio (CBS, 2006). Poverty is not evenly spread across the country. A poverty map prepared by CBS/WFP/WB identifies areas where high concentrations of poverty can be found. The incidence of poverty is highest in the Hills and Terai of the Far- and Mid- Western Development Regions as well as in the Hills and Mountains of the Eastern Development region. If poverty is measured by means of direct calorie intake, the Mountain belt has the highest poverty count. This difference is most likely due to unavailability of food items in the remote mountainous zone. The highest concentration of poor people can be found in the Terai due to a much higher population density as compared to the Hills and Mountains. External food assistance is required to the most vulnerable households up to the harvesting of the winter crop which starts from May to August, depending on the geographic area. This external food assistance is critically important for hill and mountain districts, in the form of targeted food aid. The most critical period is from February to May which coincides with the post-summer harvest period and the winter crop growing season. In addition, longer term strategies such as rehabilitation and construction of irrigation systems are required.

\section{Recommendations}

This is the third consecutive year that Nepal has faced drought and other adverse weather conditions. It considerably affected last year's winter crop, particularly in the Far- and MidWestern regions. This monsoon, the rainfall was again below normal affecting the paddy production, particularly in the Eastern Terai, turning districts that typically are food surplus into food deficit districts. Faced by these conditions, livelihoods of marginal farmers and landless laborers are being compromised with some communities having high adoption rates of negative coping strategies, and decreased access to alternative income opportunities. To improve the food security status of poor households and the overall national food security, a dual approach of a set of immediate measures and longer-term interventions are recommended by both Government of Nepal and development partners. Immediate and longer term response measures are described below: 


\section{Immediate measures}

- In order to address continued food insecurity experienced by drought-affected communities in the Mid- and Far-West, it is recommended that Government of Nepal and other development partners specially WFP continue its emergency food assistance operations in those areas.

- $\quad$ For food aid to drought-affected populations living in the Eastern Terai, it is suggested that a food for work mechanism be applied as a condition for food aid distribution. By using this mechanism it will not only help to address short-term food insecurity, but will protect and build community assets and help to accrue longer term impacts on food production. Rehabilitation of irrigation schemes, rural road construction, and installation of treadle pumps for irrigation are suggested activities to be undertaken.

\section{Longer term measures}

The measures outlined below should be incorporated into a longer-term agricultural response policy developed by the MOAC in order to improve crop productivity in Nepal. Development agencies should seek synergy by coordinating their activities and developing complementary projects with these recommendations in mind.

- $\quad$ NFC quota for food distribution needs to be increased and its role as a food safety net provider in remote areas strengthened.

- Where access to markets are difficult, the MOAC needs support in setting up of community managed grain banks for bridging lean period between harvesting periods.

- In addition, a control system on fertilizer quality needs to be strengthened. In order to enhance access to production inputs increased coverage for micro-credit schemes is recommended.

- In order to better monitor the crop situation and to provide early warning information, the MoAC's crop monitoring system should be strengthened.

- $\quad$ Areas under irrigation are much less affected by drought conditions than rain fed areas. Bringing more agricultural land under irrigation through rehabilitation of existing irrigation systems, surface, shallow and deep tube wells, is essential to prevent future crop failures due to drought. In addition, to prevent further soil erosion, river training schemes need to be supported.

- Crop diversification needs to be further promoted with crops suitable to local conditions such as potato, groundnut, cardamom, pointed gourds, and herbal plants promoted within appropriate regions. 


\section{ANNEXES}

Annex Graph 1: Trend in paddy production

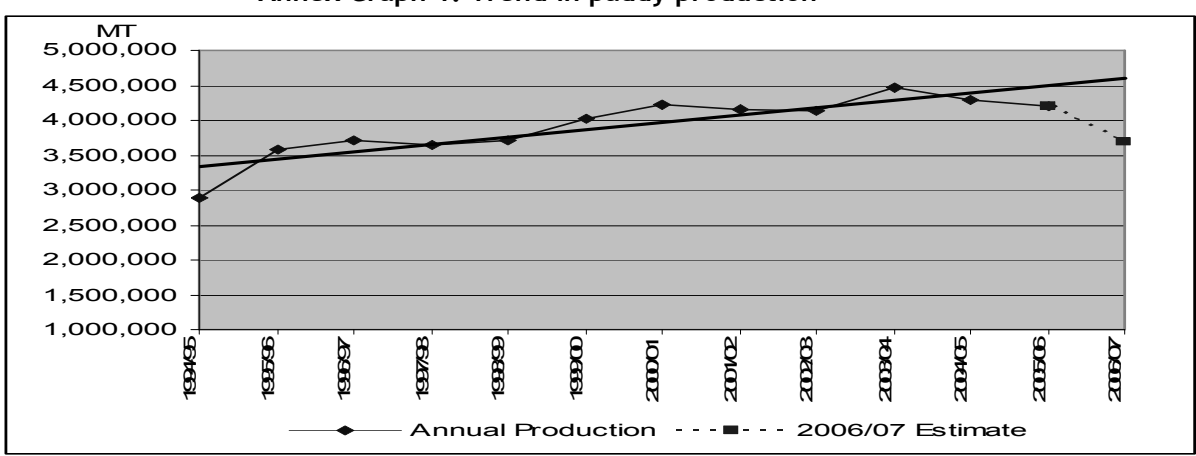

Annex Graph 2 - Trend in maize production

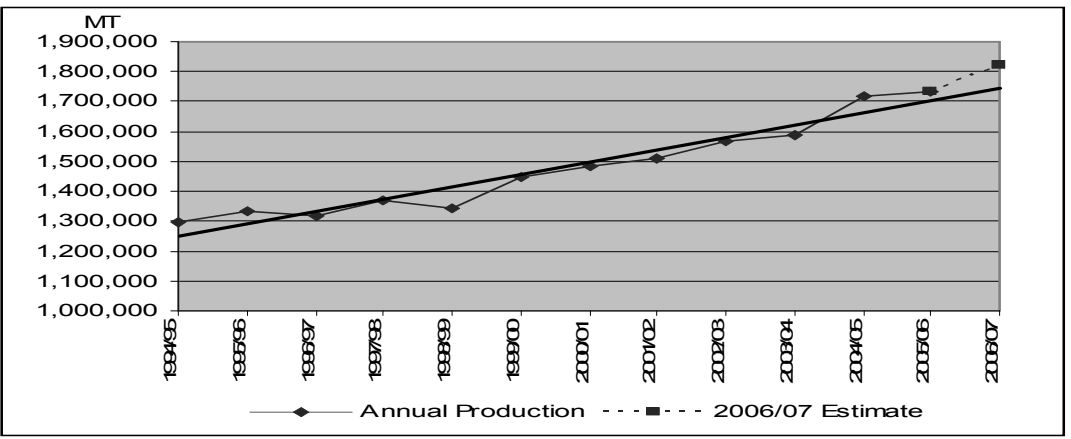

Annex Graph 3 - Trend in millet production

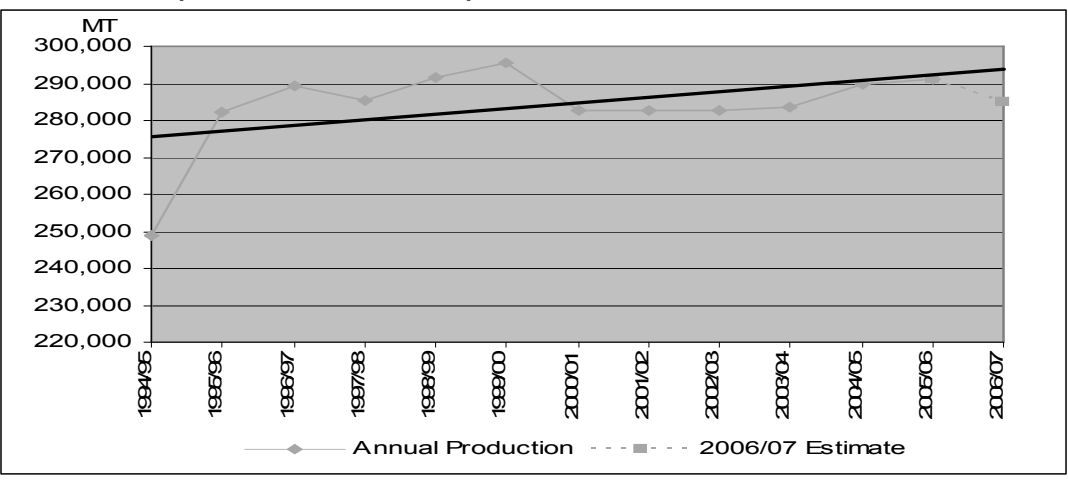




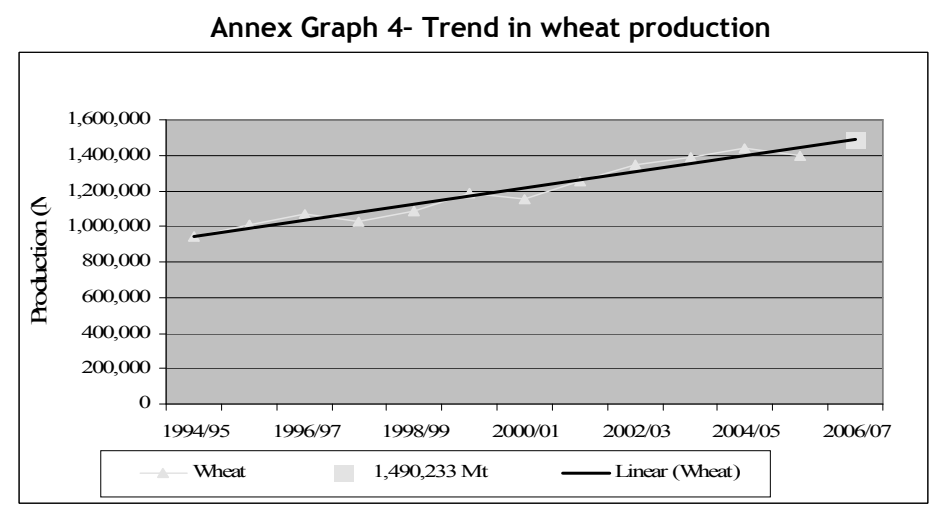

Annex Table 1. Summer crop production estimates

\begin{tabular}{|c|c|c|c|c|c|c|c|c|c|}
\hline & \multicolumn{3}{|l|}{ Paddy } & \multicolumn{3}{|l|}{ Maize } & \multicolumn{3}{|l|}{ Millet } \\
\hline & $\begin{array}{l}\text { Area } \\
(\mathrm{Ha})\end{array}$ & $\begin{array}{l}\text { Prod. } \\
\text { (MT) }\end{array}$ & $\begin{array}{l}\text { Yield } \\
(\mathrm{Kg} / \mathrm{Ha})\end{array}$ & Area $(\mathrm{Ha})$ & $\begin{array}{l}\text { Prod. } \\
\text { (MT) }\end{array}$ & $\begin{array}{l}\text { Yield } \\
(\mathrm{Kg} / \mathrm{Ha}) \\
\end{array}$ & $\begin{array}{l}\text { Area } \\
(\mathrm{Ha})\end{array}$ & $\begin{array}{l}\text { Prod. } \\
\text { (MT) }\end{array}$ & $\begin{array}{l}\text { Yield } \\
(\mathrm{Kg} / \mathrm{Ha})\end{array}$ \\
\hline Mountain & 62,263 & 120,172 & 1,930 & 88,288 & 163,609 & 2,000 & 53,174 & 53,407 & 1,000 \\
\hline$\%$ Change & -3.70 & -6.60 & -3.00 & -0.50 & 6.70 & 7.20 & 2.10 & -1.70 & -3.80 \\
\hline Hill & 367,710 & 933,852 & 2,540 & 613,774 & $1,273,111$ & 2,074 & 200,186 & 219,556 & 1,097 \\
\hline$\%$ Change & -3.60 & -7.70 & -4.20 & 2.90 & 4.70 & 1.70 & 1.10 & -2.20 & -3.30 \\
\hline Terai & $1,009,552$ & $2,626,815$ & 2,602 & 168,339 & 383,205 & 2,276 & 11,800 & 11,850 & 1,004 \\
\hline$\%$ Change & -8.50 & -14.40 & -6.50 & 1.40 & 5.10 & 3.60 & 1.90 & -2.10 & -3.90 \\
\hline Nepal & $1,439,525$ & $3,680,839$ & 2,557 & 870,401 & $1,819,925$ & 2,091 & 265,160 & 284,813 & 1,074 \\
\hline \multicolumn{10}{|c|}{ Percentage change compared to last year } \\
\hline $\begin{array}{l}\text { E. } \\
\text { Region }\end{array}$ & -14.8 & -23.4 & -10.1 & -1.2 & 3.8 & 5.1 & -1.6 & -4.4 & -2.8 \\
\hline $\begin{array}{l}\text { C. } \\
\text { Region }\end{array}$ & -7.8 & -9.7 & -2.0 & 1.2 & 2.6 & 1.4 & 1.5 & 0.3 & -1.2 \\
\hline $\begin{array}{l}\text { W. } \\
\text { Region }\end{array}$ & -0.1 & -6.7 & -6.6 & 5.4 & 6.0 & 0.5 & 0.9 & -2.8 & -3.7 \\
\hline $\begin{array}{l}\text { MW. } \\
\text { Region }\end{array}$ & -2.4 & -7.8 & -5.5 & 6.0 & 4.8 & -1.1 & -0.3 & -3.2 & -2.9 \\
\hline $\begin{array}{l}\text { FW. } \\
\text { Region }\end{array}$ & 2.4 & 2.6 & 0.2 & -0.8 & 17.6 & 18.6 & 25.9 & 7.7 & -14.5 \\
\hline Nepal & -7.09 & -12.55 & -5.88 & 2.29 & 4.93 & 2.58 & 1.33 & -2.10 & -3.39 \\
\hline \multicolumn{10}{|c|}{ Percentage change compared to trend forecast } \\
\hline Nepal & & -21.0 & & & 5.0 & & & -3.0 & \\
\hline
\end{tabular}

Source: MOAC 
Annex Table 2 Food Balance Situation

\begin{tabular}{|l|l|l|l|l|}
\hline Year & Prod. & Req. & Balance & SSR \\
\hline $1994 / 95$ & $3,397,760$ & $3,882,915$ & $-485,155$ & 87 \\
\hline $95 / 96$ & $3,913,878$ & $3,948,229$ & $-3,451$ & 99 \\
\hline $96 / 97$ & $3,972,587$ & $4,079,135$ & $-106,548$ & 97 \\
\hline $97 / 98$ & $4,027,348$ & $4,178,077$ & $-150,729$ & 96 \\
\hline $98 / 99$ & $4,097,612$ & $4,279,491$ & $-181,879$ & 95 \\
\hline $99 / 00$ & $4,451,939$ & $4,383,443$ & 68,496 & 101 \\
\hline $2000 / 01$ & $4,513,179$ & $4,430,128$ & 83,051 & 101 \\
\hline $2001 / 02$ & $4,543,049$ & $4,463,027$ & 80,022 & 101 \\
\hline $2002 / 03$ & $4,641,466$ & $4,565,820$ & 75,646 & 101 \\
\hline $2003 / 04$ & $4,884,371$ & $4,671,344$ & 213,027 & 104 \\
\hline $2004 / 5$ & $4,942,553$ & $4,779,710$ & 162,843 & 103 \\
\hline $2005 / 6$ & $4,869,436$ & $4,890,993$ & $-21,557$ & 99 \\
\hline $2006 / 7$ & $4,753,340^{*}$ & $4,941,089$ & $-187,749$ & 96 \\
\hline
\end{tabular}

Note: *Given an optimistic scenario of 1.5 million MT of wheat

Source: ABPSD, MOAC, November 2006

Annex Table 3 Self--sufficiency in food grains production in Nepal

\begin{tabular}{|c|c|c|c|c|c|c|c|c|}
\hline $\begin{array}{l}\text { Ecological } \\
\text { belt }\end{array}$ & Particulars & $\begin{array}{l}\% \text { of } \\
\text { population }\end{array}$ & East & Central & West & $\begin{array}{l}\text { Mid } \\
\text { West }\end{array}$ & $\begin{array}{l}\text { Far } \\
\text { West }\end{array}$ & Nepal \\
\hline \multirow[t]{2}{*}{ Mountain } & Production & \multirow[b]{2}{*}{8} & 79 & 97 & 20 & 30 & 41 & 249 \\
\hline & SSR (\%) & & 101.3 & 90.7 & 36.8 & 50.0 & 54.2 & 76.5 \\
\hline \multirow[t]{2}{*}{ Hills } & Production & \multirow[b]{2}{*}{44} & 347 & 458 & 584 & 271 & 86 & 1,746 \\
\hline & SSR (\%) & & 102.9 & 64.4 & 102.4 & 90.7 & 53.2 & 84.0 \\
\hline \multirow[t]{2}{*}{ Terai } & Production & \multirow[b]{2}{*}{48} & 769 & 841 & 397 & 294 & 2319 & 2,532 \\
\hline & SSR (\%) & & 127.3 & 117.7 & 124.5 & 131.1 & 128.9 & 124.1 \\
\hline \multirow[t]{2}{*}{ Nepal } & Production & \multirow[b]{2}{*}{$100 \%$} & 1,195 & 1,337 & 983 & 595 & 358 & 4,468 \\
\hline & SSR (\%) & & 117.3 & 87.2 & 110.0 & 102.1 & 85.9 & 100.5 \\
\hline
\end{tabular}

(Average of 2000/01 -- 2002/03) (In thousand MT) Source: MDD, 2000-2004, Special Issues

Note: SSR is Self Sufficiency Ratio

\section{REFERENCES}

1. CBS, WFP: 2006: Small area Estimation of Poverty, Calories Intake and Malnutrition in Nepal

2. Economic Survey, Ministry of Finance/GON, 2005

3. Nepal Living Standard Surveys

4. Preliminary Weather Summary of Nepal, June 2006 (GoN, Department of Hydrology and Meteorology)

5. UNDP, 2005: Human Development Report, 2005, United Nations Development Program, New York.

6. WFP Food Security Bulletin 12, January-February 2006

7. World Bank, 2006: Country Overview. 